NBER WORKING PAPER SERIES

\title{
PROPERTY RIGHTS TO FRONTIER LAND AND MINERALS: US EXCEPTIONALISM
}

\author{
Gary D. Libecap \\ Working Paper 24544 \\ http://www.nber.org/papers/w24544 \\ NATIONAL BUREAU OF ECONOMIC RESEARCH \\ 1050 Massachusetts Avenue \\ Cambridge, MA 02138 \\ April 2018
}

Prepared for the Handbook of Cliometrics, 2nd ed., edited by Claude Diebolt and Michael Haupert. Very helpful comments and direction were provided by Daron Acemoglu, Susan Carter, Robert Ellickson, Eric Edwards. Stanley Engerman, Richard Epstein, Peter Lindert, Deirdre McCloskey, Larry Neal, Claire Priest, Richard Sutch, Tom Weiss, and Gavin Wright. Excellent research assistance was provided by Chester Lindley. The views expressed herein are those of the author and do not necessarily reflect the views of the National Bureau of Economic Research.

NBER working papers are circulated for discussion and comment purposes. They have not been peer-reviewed or been subject to the review by the NBER Board of Directors that accompanies official NBER publications.

(C) 2018 by Gary D. Libecap. All rights reserved. Short sections of text, not to exceed two paragraphs, may be quoted without explicit permission provided that full credit, including () notice, is given to the source. 
Property Rights to Frontier Land and Minerals: US Exceptionalism

Gary D. Libecap

NBER Working Paper No. 24544

April 2018

JEL No. K11,N5,N51,N56,Q15,Q24,Q32,Q35

\begin{abstract}
Property rights are the most fundamental institution in any society. They determine who has decision-making authority over assets and who bears the costs and benefits of those decisions. They assign ownership, wealth, political influence, and social standing. They make markets possible; define timelines; and provide incentives for investment, innovation, and trade. They mitigate the losses of open access and provide the basis for long-term economic growth. Economists and economic historians have long recognized the importance of secure property rights for economic outcomes. Other political economy, philosophy, historical, and legal literatures emphasize different, but critical attributes based on how property rights are allocated and to whom. The linkages among the social, political, and economic effects are examined here with respect to US and Latin American frontier land and minerals. Property rights were sharply different across the two frontiers with apparent long-term consequences for economic growth, innovation, wealth distribution, private investment in public goods, as well as social and political stability. The distinct assignment of property rights to land and minerals is likely a basis for long-term US exceptionalism in economic performance, individualism, mobility, and optimism. The mechanisms through which property rights to land in a frontier society affect outcomes in a contemporary, highly urban one are complex. Because property rights to land were broadly distributed, Americans could participate in capital markets using land as collateral. This ability shaped opinions regarding markets, capitalism, and individual opportunity. In the 21 st century, these critical attributes may be eroding, inviting more analysis from economists and economic historians.
\end{abstract}

Gary D. Libecap

Bren School of Environmental Science

and Management and Economics Department

University of California, Santa Barbara

Bren Hall 4412

Santa Barbara, CA 93106-5131

and NBER

glibecap@bren.ucsb.edu 
"If a man owns a little property, that property is him....it is part of him....in some ways he's bigger because he owns it." John Steinbeck, The Grapes of Wrath, (1939, 1976, 48).

\section{Introduction.}

The above quotation points to attributes of property rights that are more individualistic, social, and political than are those emphasized in most economic discussions. Nevertheless, there are direct linkages across these characteristics, and emphasizing the relationships is the focus of this Chapter. Attention is directed to frontiers in North and South America where property rights were distributed to land and minerals in very dissimilar ways, seemingly leading to starkly different consequences-economic, political, and social. These varying frontier experiences appear to have had long-term consequences. Frontiers provide a natural experiment because, by definition, they are areas where new rights to resources are emerging. The discussion is based on the existing literature and does not provide tests of hypotheses regarding property rights and various outcomes. Causality between property rights structures and observed variation in immigration patterns, middle class development, innovation, social and political cohesion, individualism, reduced reliance upon the state, private investment in public goods as well as, long-term economic growth seems, however, to be supported by available research.

Property rights are the most fundamental institution in any economy and society. The economics and economy history literatures explore the role of secure property rights in mitigating the losses of the common pool, in promoting markets and exchange, and in encouraging investment. These facilitate long-term economic growth and welfare. Older political economy, philosophy, and history literatures, as well as growing legal scholarship, point to widespread ownership of land and related resources in molding social, economic, and political relationships, and the role of individuals relative to the state. In those literatures, the existence of secure private property rights leads to more independent, self-reliant, and individualistic citizens. They innovate, are politically conservative, and invest in local public goods. They rely on rents they discover and generate. The state is less important than the market, and the economy in turn is less centralized, more atomistic, market-based, and supportive of entrepreneurship. 
For the US, the frontier is defined according to the US Census as an unsettled region where population density was less than 2

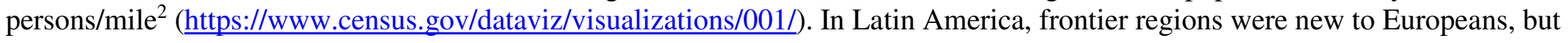
often had denser native occupation, and there were multiple frontiers. Nevertheless, for land and minerals the definition of the frontier is used here for European settlers in the region. The settlement of temperate North America by European migrants, molded in part by the English common law of property and contract, along with the actions of colonial and US courts and legislatures, granted access to and ultimate ownership of unimaginable riches to common individuals in a piecemeal fashion. In Latin America, land and mineral ownership was retained by the sovereign with use rights to large tracts of land granted to political and economic elites. Mineral rents largely were reserved by the crown. In the post-colonial period, hierarchical, centralized control continued, although individuals could obtain title to their land. Minerals remained owned by the state. These differences in the property rights to land and minerals allocated to individuals by the state between North and South America appear to have had long-lasting, important economic, political, and social effects that are collected from the relevant literatures and described below. The outcomes underscore the perhaps

underappreciated far-reaching and enduring impact of the nature of property rights to fundamental resources that exist in any society. They go far in offering an explanation for contemporary differences observed across nations and across times in development, equity, opportunity, entrepreneurship, and social and political stability.

\section{The Economic Institutions of Property Rights.}

Property rights critically shape economic behavior by fixing incentives for resource use, investment, exchange, and inheritance. They set time frames and define the decision makers for such actions. They determine flows of associated benefits and costs and designate who will receive or bear them. Externalities arise from incomplete property rights, when decision makers do not internalize the full benefits and costs of their actions. Depending on the size of the imprecision in definition of property rights, incentives are distorted, leading to losses in potential resource value and welfare. Property rights can be informal (implicitly recognized) or formal (legally documented) and can range from state ownership to group rights to private property rights. In all cases to be stable, they must be socially-sanctioned and often are enshrined in established law.

Property rights can exist with almost any imaginable array of attributes. They may a). be held by a single party or be divided with one party having use rights and another actual ownership; b). be permanent or short-term; c). have comprehensive or restricted authority over use, exchange, investment, and assignment to heirs; d). completely direct costs and benefits to rights holders or split costs and benefits among multiple entities, including users, sovereign rulers, politicians, and bureaucrats; e). be well defined or imprecise; and f). be secure or insecure. This assortment of possible attributes leads to a similar multiplicity of economic outcomes for the same resources and decision makers. 
Economists and economic historians have long recognized the critical role of property rights in determining economic performance. North and Thomas (1973) emphasize the emergence of different freehold rights between England and Holland and France and Spain as a key source in differential patterns of economic growth. When reasonably well-defined and durable, private property rights critically contribute to economic growth (Davis and North, 1971; North, 1981,1990; Acemoglu, Johnson and Robinson, 2001, 2005; Mehlum, Moene, and Torvik, 2006; Rodrik, 2008; Dixit, 2009; Besley and Ghatak, 2010; North, Wallis, and Weingast, 2009; Acemoglu and Robinson, 2012; Alston, Alston, Mueller, and Nonnenmacher, forthcoming, 2018)). They facilitate greater investment when returns are uncertain or delayed (Besley, 1995; Jacoby, Li, and Rozelle, 2002; Galiani and Schargrodsky, 2010; Hornbeck, 2010). They allow for the development of markets (Grief, Milgrom, and Weingast, 1994; Barzel, 1997; Dixit, 2009; Edwards and Ogilvie, 2012). And finally, they reduce rent dissipation associated with common-pool resources (Gordon, 1954; Scott, 1955; Cheung, 1970; Johnson and Libecap, 1982; Wiggins and Libecap, 1985; Grafton, Squires, and Fox, 2000; Wilen, 2005;

Costello, Gaines, and Lynham, 2008).

The principal long-term economic benefits of property as an institution, arise from private property rights (Merrill and Smith, 2010). Although group management of resource access and use has been effective in overcoming the losses of the common pool (Ostrom, 1990), the conditions for successful collective action may be quite limited (Cox, Arnold, and Villamayor Tomás, 2010). Moreover, communal rights may not facilitate markets and asset trade outside the group, nor risky, disruptive innovation within it. Finally, neither theory, nor empirical evidence indicate success with state-owned rights or socialism in promoting long-term economic growth or in mitigating open-access losses (Barro, 1991; Grafton, Squires, and Fox, 2000; Costello, Gaines, and Lynham, 2008).

The dominant performance of private property rights, relative to others, lies in the more complete alignment of private and social benefits and costs; lower transaction costs in decisions (initial assignment of rights may entail high transaction costs, Libecap, 2008); market development; and incentives for value or rent creation (Ellickson, 1993, 1327; Allen, 2011). With state ownership or control, value may be lost, even if externalities are addressed. While private property rights assign ownership to individuals, group or state property rights separate ownership from actual decision making, potentially generating distortions with possibly high welfare losses. There can be externalities associated with private ownership, and in that case, one question is why the property rights are incomplete in the first place, as compared to traditional calls for state regulation or taxation (Pigou, 1920; Coase, 1960; Dahlman, 1979). Externalities are far less likely for resources, such as land and minerals, where property rights can be defined and enforced at relatively low transaction costs. For other resources, such as air, water, or fish stocks, property rights are more difficult to define and enforce, and government ownership or regulation of access and use is more prevalent (Libecap, 2008). For some resources, such as forestland and rangeland in the US, political demand by advocacy groups, beginning in the late $19^{\text {th }}$ century led to their retention by 
the state, rather than assignment to private parties (Libecap, 2007). The underlying arguments for retention by the state were not fundamentally due to an inability to define property rights effectively (Libecap, 1981; Libecap, 2007). The key problem for state regulation or ownership in either of these cases is that neither politicians nor bureaucrats are full residual claimants to the benefits and costs of their actions in the way that private owners are, so that incentives and outcomes differ, often creating other, and perhaps costlier, externalities (Libecap, 2016).

\section{Social and Political Institutions of Property Rights: Pre-Frontier.}

Historically in Europe, ownership of land and all natural resources lay with the Creator, as represented on earth by the sovereign. The landed nobility had use rights that were held at the pleasure of the sovereign, and much of English and European history involved conflicts between the crown and the nobility over the extent and nature of those rights, their security, and taxation. Those who actually worked the land, thousands of serfs, peasants, and tenant farmers had little or no authority over it and captured few of the benefits, with most rents taxed away by their feudal masters and passed on in-part to the crown. Those who used the land were bound to it. This very centralized setting was static so as not to upset key relationships, and there was little incentive among tillers of the soil and grazers to innovate, and they had little political role in the society.

Political economists and philosophers during the European Enlightenment, including Adam Smith, John Locke, Jeremy Bentham, J.J. Rousseau, John Stuart Mill, David Ricardo, Edward Wakefield, and Robert Torrens (Winch, 1965; Ellickson, 1993; Linklater, 2013; Priest, forthcoming 2019) debated the role of individuals in society, their potential for advancement, relationship with the state, and the critical impact of widespread private ownership of land for advancing individual and resource potentials. The implications of land ownership as a threat for an authoritarian state also were clearly understood by Marx, Lenin, Stalin, and Mao Zedong. Land as a fundamental resource was key and its ownership had contagious effects on the entire economic, social, and political orders in the short and long run.

The colonization of western hemisphere frontiers during the $16^{\text {th }}$ and $19^{\text {th }}$ centuries by England, Holland, France, Spain, and Portugal was molded by very different views of land and minerals distribution and ownership. In the Spanish, Portuguese, and French colonies, the process was controlled centrally by the crown. There was little emphasis on large-scale emigration with land being granted in large tracts to political elites. Ownership remained with the crown, and those who received land grants held them at its pleasure. For English North America, the nature and distribution of property rights were in sharp contrast. Individuals, not the crown, were the ultimate owners of land, and for the most part, it was allocated in small plots. Vast numbers of immigrants were attracted by 
the opportunity to secure land, and their ability to own it had profound consequences in the development of English colonies and subsequently, the US.

The Magna Charta of 1215, the Glorious Revolution of 1688, land enclosures that broke up communal holdings, particularly in the $18^{\text {th }}$ and $19^{\text {th }}$ centuries, and the English agricultural and industrial revolutions, ended the ultimate ownership of land by the crown as the representative of God on earth. Comparatively static, feudal and communal obligations were broken. More materialistic economic and democratic political objectives became ascendant. The legal basis for alienable, private property in land became part of the common law. Ordinary individuals could own land and enjoy the benefits of using, investing, and trading it. William Blackstone commented in 1766 on the implications: "There is nothing which so generally strikes the imagination, and engages the affections of mankind, as the right of property; or that sole and despotic dominion which one man claims and exercises over the external things of the world, in total exclusion of the right of any other individual in the universe ...." (quoted in Ellickson, 1993, 1317). English colonization and migration to North America were driven by these ideals Ely $(2008,13)$. Those who migrated to and occupied frontier land eventually held it in fee simple as independent owners and not as a dependent peasantry (Supreme Court Justice, Story, 1858, 160).

\section{Property Rights to Land on the US Frontier.}

Claire Priest (forthcoming, 2019) summarizes much of the early literature and key elements of colonial and early federal land law. She argues that the colonists brought with them English laws, customs, and legal institutions and then modified them through the statutory enactments of local representative assemblies and rulings of common law courts. Gradually, colonial and early US property law became quite distinct from that in England, fundamentally transforming the economic, political and social structure of the country (Priest, 2019, Introduction, 2-3). Property rights in land became a liquid source of wealth, to be bought and sold and used to obtain credit. Because land was the most basic resource, its widespread ownership became the catalyst for colonial economic and political development. The ownership of property made individuals special stakeholders in the society and dispersed political and economic power from elites in a manner that had not occurred in England. The easy circulation of land in the market facilitated extensive property ownership, undermining privileged inheritance and inalienability. Dynamic, open land markets became an essential ingredient for the credit system and its ability to support growth of a middle class as well as to spur investment and innovation throughout the economy (Priest, forthcoming 2019, Chapter 1, 7).

There were many commentaries on the benefits of land ownership and exchange. Benjamin Franklin saw it as the way for ordinary persons to improve their position in life and that of their children (Franklin, 1751, quoted in McCulloch, 1845, 254). Thomas 
Jefferson saw a nation of numerous, small freeholders not only as good economics, but good politics. The seemingly endless abundance of frontier land provided the perfect opportunity to create a society composed of small, independent, freeholding farmers that could support a republican form of government. Such citizens with an attachment to the land and to the country had virtue and a common interest in political stability and social cooperation. He notably stated that: "The earth is given as a common stock for man to labor and live on... The small landholders are the most precious part of a state" (quoted in Katz, 1976). Alexis de Tocqueville observed that being freeholders changed the way in which Americans thought of themselves and the political structure: "Why, in a quintessentially democratic country like America, does one hear no complaints about property in general such as those that often resound through Europe? Needless to say, it is because there are no proletarians in America. Since everyone has property of his own to defend, everyone recognizes property rights as a matter of principle" (de Tocqueville, 1835, quoted in Goldhammer, 2004, 273).

Later in the $19^{\text {th }}$ century as the frontier neared its end, the US Public Lands Commission endorsed the small-farm, homestead principle: "The maxim that He who tills the soil should own the soil is accepted as a fundamental principle of political economy... Small holdings distributed severally among the tillers of the soil is believed to be a fundamental condition for the prosperity and happiness of an agricultural population" (US Public Lands Commission, 1880, xxii). Frederick Jackson Turner in 1893 in his famous thesis about the role of the frontier in US political and social development went further, claiming that America ultimately was shaped by small-farm frontier settlement as the underpinning for democracy, an independent citizenry, and generalized economic wellbeing (Turner, 1893, 203). This is the notion of US exceptionalism and its dependence on frontier resource ownership emphasized here.

\section{Colonial Property Rights to Land}

The English Crown granted colonial charters that conveyed land and lawmaking authority. Some colonies began as trading companies, such as the early Virginia, Plymouth, and Massachusetts Bay Companies, and the charters were to the owners of the corporation. Other colonies were proprietorships based on grants from the Crown to an individual or a group of individuals, such as those to William Penn and Lord Baltimore, creating Pennsylvania and Maryland. A third type was the royal colony directly ruled by the crown, including New Hampshire, New York, New Jersey, Virginia, North Carolina, South Carolina and Georgia. In all cases, a Governor or Proprietor served as the top official, and assemblies of elected representatives were authorized to enact legislation (Priest, forthcoming 2019, Chapter 1, 7-15).

Land sales were seen by the crown, proprietors, shareholders, and others as a major source of revenue, and accordingly, there was a need to attract immigrants to North America, who would create small farms and cultivate the land. Large land grants, in general, were not consistent with the policy. Especially in the Middle Atlantic and Southern colonies a headright of 50 acres or more was given 
to those who would cover the transport costs of any immigrant. In repayment, the immigrant served an indenture period, 5 to 7 years, whereby they served their sponsor. Indenture contracts were supplemented later in the colonial period by redemptioners, who borrowed for their travel costs and were released from their indenture commitments upon paying off the loan (Ford, 1910, 416; Grubb, 1986; Abramitsky and Braggion, 2006). The headright policy also encouraged the importation of slaves, but indentured servants had a future as freeholders with voting rights within the colonies. The headright/indentured servant system may have accounted for $50 \%$ to $66 \%$ of white male immigration to the American colonies between 1630 and 1776, or 300,000 to 400,000 people. Slave importation, primarily in the $18^{\text {th }}$ century, was just over 255,000 , largely to Bermuda, Barbados, and the southern US colonies (Priest, forthcoming 2019, Chapter 1, 17).

High-level colonial administrators were recruited with the promise of landed estates, and they expected to profit from rising land values and sales, stimulated by rapid new settlement by small holders. To quiet titles, attract settlers, and support land exchange colonial administrators promised surveys of small parcels. Although most property boundaries followed natural terrain (metes and bounds), more systematic, rectangular survey of parcels was implemented in flat areas. Rectangular survey facilitated subdivision and sale (Ford, 1910, 329-56; Libecap, Lueck, and O’Grady, 2011).

The extensive availability of fertile land to small holders, who could secure and cultivate freeholds not only invited vast immigration, but generated an egalitarian society with high levels of real per capita income. By 1751 the British North American colonies may have had 1 million inhabitants, compared to 52,000 or so in New France and a generally small number of immigrants to the Spanish and Portuguese colonies of South America (Linklater, 2013, 79). Lindert and Williamson (2013, 2014a, 2014b) report that in 1774 the American colonies had the most equal distribution of income in the western world and per capita purchasing of income exceeded that in Great Britain. The process of distributing land on the frontier took time to sort out during the colonial period. Much of the political instability observed at the time, aside from opposition to English rule, came from frontier setters against colonial proprietors and other administrators over issues of taxation of local production, protection against natives, and overall access to land (Bacon's Rebellion, 1676; Culpeper's Rebellion, 1677; Cary's Rebellion, 1711; Shay's Rebellion, 1786; and the Whiskey Rebellion, 1791-1794. During the post-colonial period there was seemingly far less political volatility on the frontier. As described below, policies to grant land to migrants at low cost and to support their property rights and land markets became routine. The political coalition of small holders and would-be small holders, who also were land speculators and frontier territorial politicians who wanted their regions to have dense settlement so as to qualify for statehood, was a formidable one in Congress. At the same time, the federal government had no strong reason to hold on to frontier land. Until, the rise of the conservation movement, there was no advocacy for maintaining federal ownership. For reasons, land policies were promoted the distribution of frontier land to private claimants as quickly and at as low a cost as possible. As discussed below, political motives for land transfers were very different in Latin America. 


\section{Federal Property Rights Policies for Land.}

Following the end of the French and Indian War in 1763 and the Revolutionary War in 1783, frontier migrants began moving in large numbers beyond the Appalachian Mountains to the comparatively flat lands in the Ohio River Valley and elsewhere. Land in the vast new territory was distributed through direct sales from the federal government and from the issuance of military warrants, redeemable for small parcels, to compensate Revolutionary War soldiers (Ford, 1910, 359-411). Military warrants were bought and sold and were a major means of securing access to land by their ultimate holders. The Federal Land Ordinance of May 20,1785 called for the survey of all lands ceded by the states to the federal government and all additional lands acquired through purchase from native tribes. It created the Public Lands Survey System (PLSS) of grids of square townships of 6 miles square and 23,040 acres each, aligned along latitude and longitude. Each township was subdivided into 36 sections of land that could be further subdivided into half and quarter sections for purchase and sale. The survey made land a commodity with clearly defined parcel boundaries that were easily addressable (Libecap and Lueck, 2011; Libecap, Lueck, and O'Grady, 2011). Libecap and Lueck (2011, 449) estimate that the rectangular survey raised land values by $23 \%$, relative to the baseline alternative of metes and bounds that invited boundary disputes and created irregular parcel sizes and shapes that hindered market exchange. The General Land Office was created in 1812 to administer and extend the survey across the continent and to distribute additional federal lands under land laws enacted by Congress (Table 1 below). The rectangular survey reduced gaps between properties and promoted dense, rapid settlement of the frontier. The federal government offered land at fixed prices, often $\$ 1.25 /$ acre to raise revenue. This revenue objective ultimately was undermined by the inability to police squatting and occupancy and growing political demand for free land.

Figure 1 shows the movement of the frontier across the continent based on population density. In 100 years, the frontier went from the Atlantic seaboard to its announced end by the Census Bureau in 1890. As noted above, the Bureau defined the frontier as an area where population density was 2 persons/mile ${ }^{2}$ or less, and in the Figure the frontier is represented in the lightest yellow states. Land densities rose in established areas as the frontier progressed westward through time. Bazzi, Fiszbein, and Gebresilasse, (2017) provide a similar description of the frontier.

Figure 1: The Progression of the Frontier. 

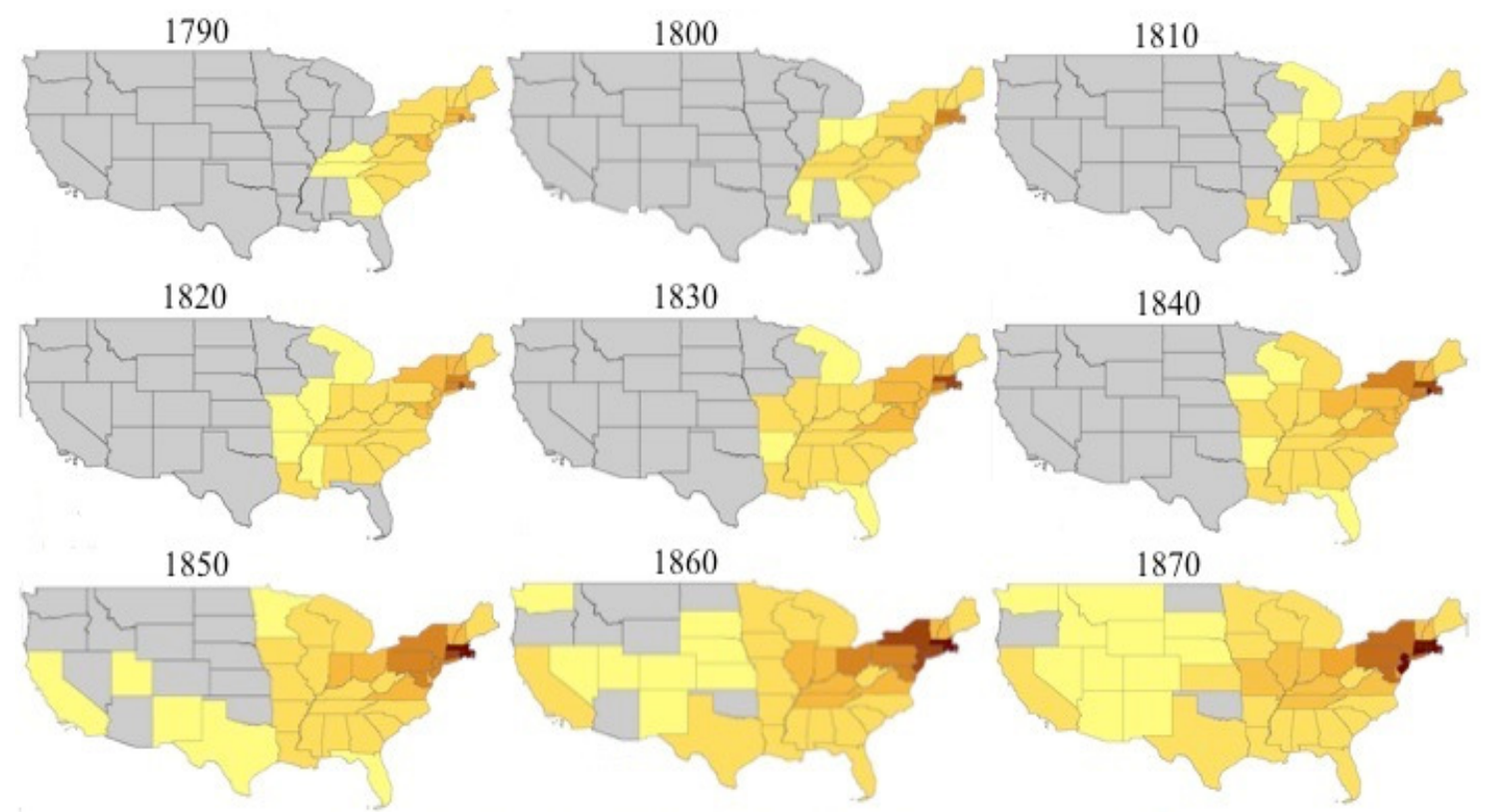

1860

1870

Population Density (People Per Square Mile)

$\square 0.0-2.0 \square 2.01-25.0 \square 25.01-50.0 \square 50.01-75.0 \square 75.01-100.0$ $>100$

Notes: State population densities from 1790 to 1870 are from the US Census. Grey states are those with missing data

US Census Bureau (2012, September 6), retrieved from https://www.census.gov/dataviz/visualizations/001/. To construct the figure, population densities for each individual state were taken from the decennial censuses for the years 1790 to 1870. ArcGIS was used to create maps with contemporary state boundaries and their respective population densities for each census.

Table 1 lists the major federal land laws enacted by Congress that distributed property rights to land and minerals on the frontier. The demand for free small freeholds was incorporated into policy, beginning with the Preemption Act of 1830 and its many amendments (Kanazawa, 1996) to accommodate and legally recognize squatter claims and on through the Homestead Act of 1862 and its adjustments. The Homestead Act effectively was ended by Congress in 1934. Under all laws, property rights to agricultural land were given out piecemeal in plots of 40 to 160 acres (later, up to 640 acres) with the requirement of occupancy and beneficial use 
(Hibbard, 1924; Robbins, 1942; Gates, 1968, 394). Through these land allocation laws, immense amounts were placed under private ownership. Under the Homestead Act, for example, some 2,758,818 original entries were made between 1863 and 1920 for 437,932,183 acres, an area larger than Alaska (Gates 1968, 799-800).

\section{Table: Federal Land Distribution Laws.}

\begin{tabular}{|c|c|c|}
\hline Law & Date & Stated Goal and Brief Impacts \\
\hline $\begin{array}{l}\text { Land Ordinance of } \\
1785\end{array}$ & May 20, 1785 & Established the Public Land Survey System. \\
\hline $\begin{array}{l}\text { Land Ordinance of } \\
1787 \text { (Northwest } \\
\text { Ordinance) }\end{array}$ & July 13,1787 & $\begin{array}{l}\text { Determined that the land south of Canada, north of Ohio, west of Pennsylvania and east of } \\
\text { the Mississippi river would be distributed by Congress, and that Congress would institute } \\
\text { governments and laws in this territory. }\end{array}$ \\
\hline Land Act 1796 & May 18,1796 & $\begin{array}{l}\text { Made the rectangular system of } 6 \text { square mile townships permanent, and determined the } \\
\text { size of sections to be sold. Set minimum land prices. }\end{array}$ \\
\hline Preemption Act & May 29, 1830 & Allowed settlers to occupy and purchase federal lands for up to 160 acres at $\$ 1.25$ an acre. \\
\hline Preemption Act & $\begin{array}{l}\text { September 4, } \\
1841\end{array}$ & $\begin{array}{l}\text { Permanently recognized preemption or squatter claims of land. Donaldson }(1884,1247) \\
\text { estimates around } 175,000,000 \text { acres were secured by individuals under the Preemption Acts. }\end{array}$ \\
\hline Graduation Act & August 3, 1854 & Reduced the minimum prices of unsold federal government from $\$ 1.00 /$ acre to $\$ 0.125 /$ acre. \\
\hline Homestead Act & May 20, 1862 & $\begin{array}{l}160 \text { acres of federal land was made available to individual actual setters that after } 5 \text { year's } \\
\text { continuous residency. }\end{array}$ \\
\hline Coal Lands Act & July 1,1864 & $\begin{array}{l}\text { Distributed coal lands at \$20/acre and allowed individuals and associations to claim } 160 \\
\text { acres and } 320 \text { acres respectively. }\end{array}$ \\
\hline Timber Culture Act & March 3, 1877 & $\begin{array}{l}\text { Applied to } 11 \text { Western semi-arid states and territories to augment Homestead Act claims. } \\
\text { Settlers paid } \$ 0.25 / \text { acre at filing and } \$ 1.00 / \text { acre when proving compliance. }\end{array}$ \\
\hline Dessert Lands Act & March 3, 1873 & Authorized an additional 160 acres to Homestead claims if 40 acres of trees were grown. \\
\hline $\begin{array}{l}\text { Timber and Stone } \\
\text { Act }\end{array}$ & June 3,1878 & $\begin{array}{l}\text { Authorized sale of land at } \$ 2.50 / \text { acre for land valuable for timber or stone in far western } \\
\text { states and territories. }\end{array}$ \\
\hline Mining Lode Act & July 26,1866 & First major mining law, allowed individuals to claim ownership of ore veins. \\
\hline Mining Act & May 10,1872 & $\begin{array}{l}\text { Second major mining law, added placer or shallow ore bodies; required a } \$ 100 \text { investment } \\
\text { in development to obtain title; procedure for obtaining title outlined. }\end{array}$ \\
\hline
\end{tabular}




\begin{tabular}{|c|c|l|}
\hline Oil Placer Act & 1897 & Recognized oil deposits as claimable as a placer ore deposit under the Mining Act of 1872. \\
\hline Stock Raising & December 29, & Authorized 640-acre homesteads to raise livestock. \\
Homestead Act & 1916 & \\
\hline
\end{tabular}

There is an extensive literature on the wealth generated from migration to and along the frontier and associated capital gains from land sales. There were benefits from arriving early in a frontier region and obtaining, improving, and selling land. Relatively poorer migrants often benefitted disproportionately and the rents generated led a more egalitarian wealth distribution than what was found in non-frontier areas. Major works include Lebergott (1985); Oberly (1986) for the period following the War of 1812; von Ende and Weiss (1993) for 1800-1860; Swierenga (1966) for 1840-1869; Kearl, Pope, and Wimmer (1980) for 1850-1870; Steckel (1989) for 1850-1860; Galenson and Pope (1989) for 1850-1870; Ferrie (1993) for 1850-1860; Stewart (2009) for 1860-1880, and Gregson (1996) for the latter part of the $19^{\text {th }}$ century. Most of the studies examine the East and West North Central regions, where production conditions supported small-farm distribution. Easterlin (1960) reveals gradual convergence in per-capita income and population patterns between 1840 and 1950 across the frontiers that are shown in Figure 1.

\section{The Private Provision of Public Goods by Land Owners}

The hypothesis that small-farm distribution of property rights to land resulted in civic virtue among freeholders and political participation as suggested by Jefferson, de Tocqueville and Fredrick Jackson Turner has not been tested. There naturally are measurement challenges and within the US there are no clear baselines for comparisons. The literature suggests such differences existed between US and Latin American frontiers as examined below. There are no comparative studies of political activity (voting participation rates, per-capita involvement in political office, politician turnover rates) that might have varied with land allocation across and along the US frontier. There is, however, suggestive evidence for public goods investment in education in the US that supports the relationship. Go and Lindert (2010,3-6) find that school enrollment and the number of teachers per capita were greater in rural northern US in the mid- $19^{\text {th }}$ century, where small farms predominated, than in the South where there was a more heterogeneous mix of constituencies and farm sizes. They also find that student enrollments in the rural north were greater than in most of Europe by 1850. Northern schools relied more than elsewhere on local public money and governance. Go and Lindert (2010) credit the autonomy of local governments and the voting power of citizens in rural communities for this education achievement.

Goldin (1998, 2001) and Goldin and Katz (2010) explore the rise of high school or secondary education in the US at the turn of the $20^{\text {th }}$ century that far outpaced that in Europe. Although the high school movement began in New England, it spread rapidly to the 
central Midwest and western US that were dominantly rural, agricultural, and in the Midwest at least, characterized by small farm ownership. The pedagogical focus was practical, pragmatic in emphasis, and egalitarian, aimed at understanding and using new technologies. Educated farmers and their children were more apt to adopt the new technologies and cropping changes underway at the time, and they needed high school education to be able to take advantage of the opportunities. Investment in general education, as compared to apprenticeships and firm (or farm)-specific training, was useful in a highly mobile society where labor would migrate to new locations and employment. School governance was decentralized with 130,000 independent school districts in America by the 1920s, locally supported and administered (Goldin, 2001, 279). The demand for and local support of practical education in rural areas is consistent with the argument that small freeholders had incentives to innovate because they captured the rents from doing so and because they had strong ties to their communities. They were motivated to contribute financially and administratively to their schools. The school districts were small and homogenous with respect to citizen incomes and educational objectives. These conditions promoted local collective action to invest in schooling.

Related evidence for the impact of small-holder ownership on the frontier on democracy and individual initiative as claimed by Turner (1893) is provided by Bazzi, Fiszbein, and Gebresilasse (2017). They map US frontiers and find that those who lived along them shared characteristics of rugged individualism, self-reliance, and opposition to government intervention and redistribution programs.

\section{Property Rights to Minerals and Oil and Gas Deposits.}

Not only were frontier lands generally distributed in small parcels, but subsurface mineral deposits and oil and gas formations were secured initially by small holders. In most countries, the subsurface estate has been owned by the crown and later the state. In the US, the Land Ordinance of 1785 included mineral lands that were to be sold to private bidders as surface lands, with reservation of $1 / 3$ of the properties to the government. As it turns out, however, minerals were not prominent in the central and eastern US, except for copper deposits in Michigan. Between 1776 and 1848, most mineral lands went to private ownership as agricultural lands and the government did not claim the minerals below them (Lacy, 1995). As the frontier moved into the far West, however, things changed. Rich gold and silver ore was found, beginning in California and then throughout the western region, and those individuals who discovered ore deposits claimed ownership as first possession even though minerals as separate resources from the surface land were not covered in the land laws until 1866. Eventually well over 600 mining camps were established throughout the West with bylaws regarding the requirements for defining, maintaining, and trading individual mining claims and arbitrating disputes over them. Figure 2 shows the range of mining camps in California in the late $19^{\text {th }}$ century and the US West. Each camp had local mineral rights bylaws. 
Figure 2: Frontier Mining Camps in California and the Far West.
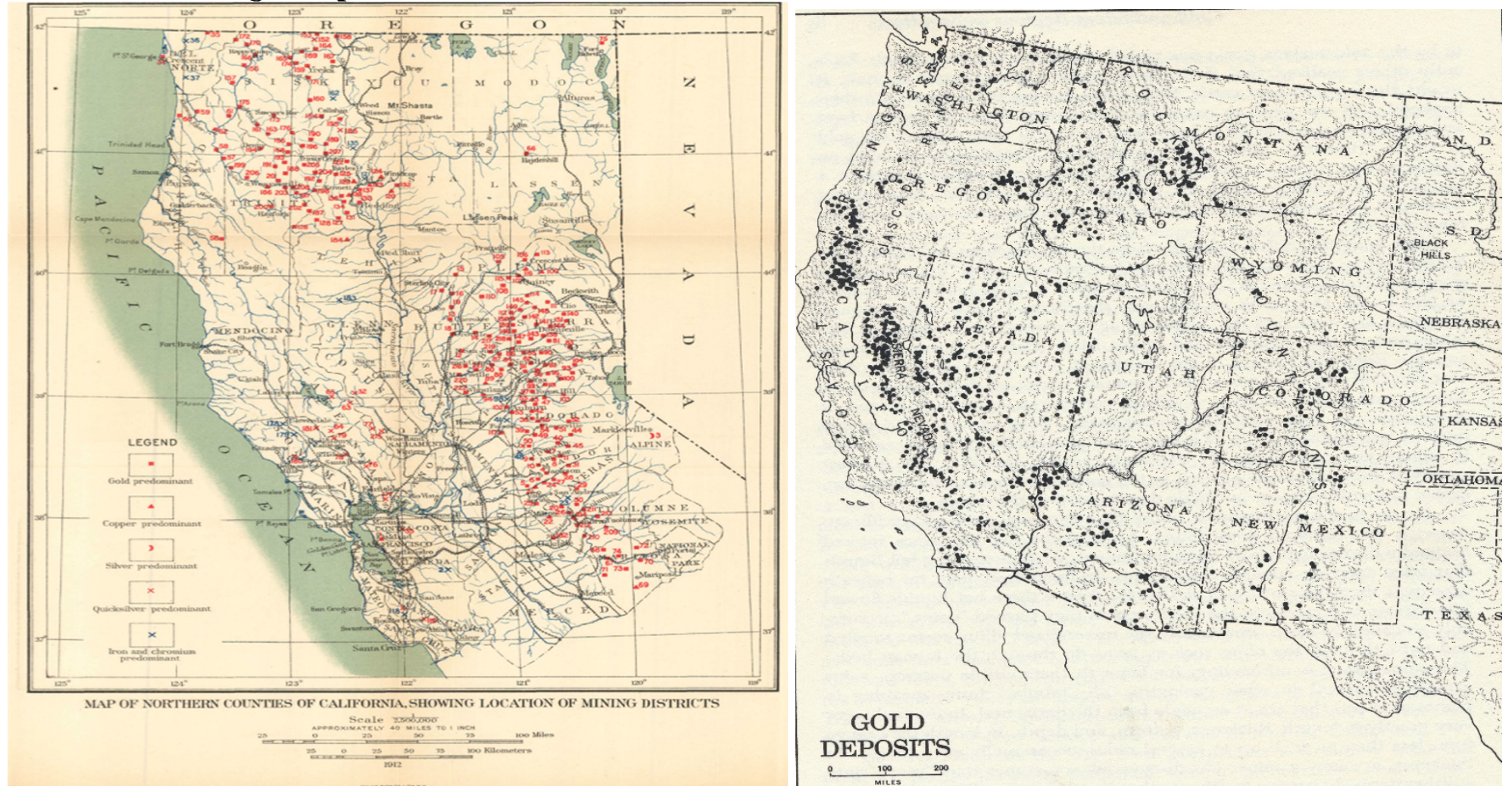

Source: California: Hill $(1912,78)$ and Gold Deposits, Paul $(1963,4)$

Libecap (1978) describes the institutional evolution of private property rights to ore on the Comstock Lode of Nevada from those defined by early mining camp rules to the actions of the territorial and state government, and ultimately the federal government in the Mining Laws of 1866 and 1872. Mineral rights could be traded, and as surface ore was depleted, requiring more capitalintensive deep-vein mining, surface mining claims were sold and consolidated into new mining companies with their shares listed on the San Francisco Stock Exchange and other capital markets. 
There is an extensive literature on mining camp rules, including that by Umbeck (1977), Clay and Wright (2005), and others noted by Libecap (2007). Drawing from public use samples from the 1850/1852 US Censuses for California, Clay and Jones (2008) analyze who went to the mining frontier in California and how they fared in their efforts to become rich. Most came from New York, Illinois, Michigan, and Wisconsin as well as Missouri, areas that once had been on the agricultural frontier. Clay and Jones find that this risky endeavor did not always pay. On average, migration may have lowered real earnings for many prospectors, relative to what they might have earned in their home locations. It was the promise of riches that drove migration and the ability to acquire individual ownership of ore in the quest for rents that drove migrants west. Overall, private property rights to minerals encouraged exploration, discovery, and production. As the mining industry developed, American mining engineering schools and technologies became world leaders. Human capital and physical technology investments in the US led the country to produce beyond what its resource endowments would have otherwise suggested.

Ownership of major oil and gas deposits also went to private individuals. Oil discoveries in Pennsylvania in 1859 and in Oklahoma, Texas, Kansas, Illinois, and California in the late $19^{\text {th }}$ century and into the $20^{\text {th }}$ century largely took place on private lands, and as noted above, surface owners held title to the minerals beneath their properties. As with minerals, private ownership and the potential to gain rents, encouraged exploration and production. Those who specialized in search were called wildcatters and they obtained leases from surface owners for exploration and later if discoveries were made, for production. By the early $20^{\text {th }}$ century prolific new oil fields were developed, particularly in the central and western US. Fabled oil fields include Spindletop, Yates, Hendrick, East Texas in Texas, Oklahoma City and Seminole in Oklahoma, and Long Beach and Kern County in California. Given relatively low costs of locating, drilling and producing in new fields, entry was easy and production soared (Libecap and Wiggins, 1984). The resulting output drove local economies, created local, self-reliant middle and upper classes, characteristic of Oklahoma and Texas today, and made the US a major world producer.

There is nothing comparable in virtually all other countries, where minerals and oil and gas deposits are owned by the state. Surface property owners may or may not share in the rents generated from new discoveries, and they often resist exploration on their properties. Incentives for exploration and production are quite different. This explains why, for example, the current rapid adoption of non-traditional production techniques (fracking) is based on US innovation and occurs dominantly on private properties in the country, where surface property owners can anticipate a share in the returns.

Although private ownership of minerals and oil and gas encouraged exploration and discovery, competitive output may have been non-optimal in an aggregate sense (Libecap and Wiggins, 1984; Clay and Wright, 2005). Figure 3 shows the many small mineral claims that often overlapped with unclear property rights, at least early in a mining camp. The rush to locate and prove or extract ore 
could have motivated excessive production. The Figure also shows town lot drilling that was found where surface ownership was extremely fragmented. With subterranean oil and gas deposits migratory, adjacent producers had an incentive to competitively drill and drain, generating classic common-pool resource losses.

It is difficult, however, to make strong welfare conclusions in either case. The tradeoffs with more centralized, large minerals or oil and gas ownership, involving potentially less discovery and innovation may offset the losses of rapid output. All in all, competitive output was mitigated by lease consolidation and large-scale hard rock mining later in the life of most mineral regions and with the unitization of oil and gas fields that designated a single firm to develop a hydrocarbon formation (Wiggins and Libecap, 1985).

Figure 3: Fragmented Minerals and Oil and Gas Ownership, Goldfield, Nevada, 1905 and Long Beach, California, 1920.

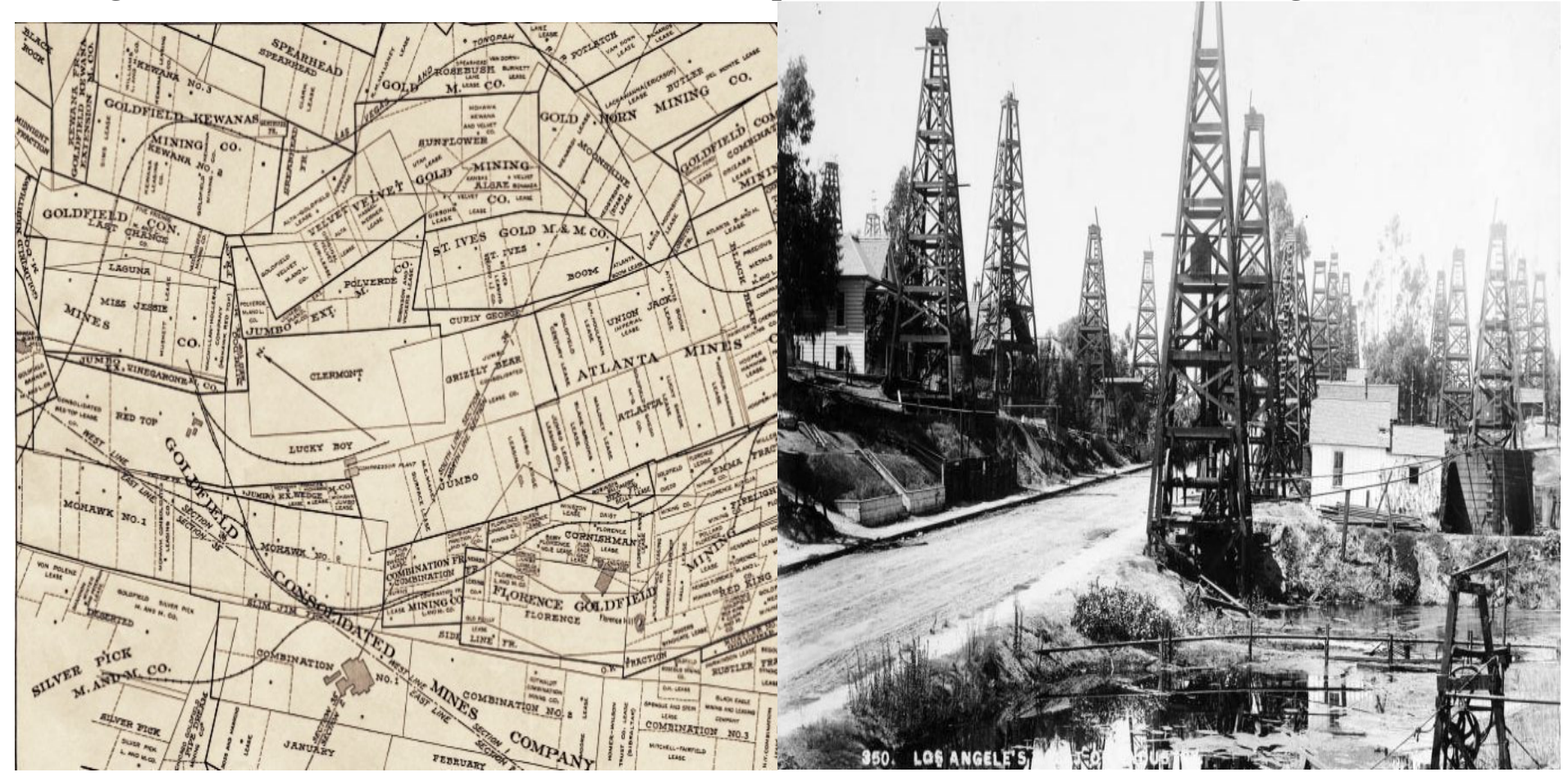


Source: https://www.mininghistoryassociation.org/Meetings/Tonopah/Goldfield\%20Claims.jpg; http://texasalmanac.com/topics/business/history-oildiscoveries-texas, https://www.kcet.org/shows/lost-la/when-oil-derricks-ruled-the-la-landscape (2011)

\section{Property Rights on Latin American Frontiers.}

Besides England of course, the western hemisphere was colonized by France (largely in Canada), Portugal (Brazil), and Spain (Central and South America) with limited colonization by Holland, Russia, and Sweden. Property rights to land and minerals were starkly different in Latin America, providing an opportunity to examine the consequences. The English language literature on frontier resource ownership is smaller and only generalized conclusions are presented here. Nevertheless, the diverse patterns relative to the US are quite clear (Alston, Harris, Mueller, 2012). The differences in economic outcomes across the US and Latin American frontiers are in part attributable to the factors underscored by economists and economic historians on the clarity, enforcement, and durability of the property rights to land and minerals provided in the two regions. In Latin America, property rights were ambiguously defined between the crown/state and private individuals, creating uncertainty as to decision making, net rent capture, and durability. Shortterm, extractive practices often were the result. Other differences in outcomes are attributable to the factors underscored in the political science, historical, legal, and other economics and economic history literatures. Property rights to land and minerals were distributed in a centralized way in large blocks to privileged parties, not in a decentralized manner to common people as in the US. The political and social power structures that emerged in the two settings were accordingly, very distinct, leading to lasting effects in political stability, social interactions, individual mobility and optimism, and economic growth,

Hennessy (1978) provides a summary of experiences on multiple frontiers in Latin America. Unlike the relatively orderly progression across North America shown in Figure 1 above, Latin American frontiers varied within and across countries. Latin America was formed of generally extractive colonies (Acemoglu, Johnson, and Robinson, 2001). The process of European migration and settlement was more centralized and limited, very different from English colonization in North America (Engerman and Sokoloff, 1997, 279; Acemoglu, Johnson, and Robinson, 2001; Linklater, 2013, 77). Ownership of land and minerals was retained by the crown in the colonial period and mineral ownership continued to be held by the state in post-colonial periods. In the colonies, use rights to land were granted by the Spanish and Portuguese crowns in large tracts to political elites who paid tithes or quit rent payments (Hennessy, 1978, 14, 49; Garciá-Jimeno and Robinson, 2011). Large-scale immigration of the kind that occurred in the US was both relatively unattractive because of limited access to desirable land and officially discouraged due to concerns in home countries of population shortages. The experience of common people on the land in Spain and Portugal was very different from their English counterparts who already had familiarity with broad private land ownership prior to emigration. Some 243,000 immigrants may have 
arrived in Latin America in the first 100 years of colonization along with perhaps 7 million more between 1820 and 1920 , as compared to 34 million to the US (Hennessy, 1978, 17).

Hennessy argues that long-term economic underperformance and political conflicts in Latin America have their origins in the initial land distribution (Hennessy, 1978, 2). It created enduring political and social elites and established internal country conditions that have influenced subsequent immigration, urbanization, and industrialization. Land grants--latifundia, encomienda, sesmarias, estancias, haciendas--not homesteads, were the typical rural institution. The estates often were near-feudal organizations with natives and immigrant farm laborers bound to the land and the patriarchal structure (Hennessy, 1978, 39). Others worked land in or near the grants as sharecroppers and tenants, with payments or crop shares to the large land holders (Leff, 1997; Chowning, 1997). Mandatory labor conscriptions were assessed in native communities for working the mines of Bolivia and Peru via the Mita (Arad, 2013, 41). There was little active smallholder participation in land or resource markets in the way that occurred in North America. Ownership and wealth were highly concentrated as were the political structures (Frank, 2001; Arad, 2013). Relative to the US frontier, a much smaller agricultural land or minerals-based middle class developed. Privileged locals invested in agricultural export industries and may have neglected or resisted other development opportunities that could undermine their positions.

Engerman and Sokoloff (1997, 265-266; 2012) and Acemoglu, Johnson, and Robinson (2001, 2002, 2005) point to factor endowments, climate and disease environments, densities of native populations, along with general institutional differences emanating from the source countries. They argue that these factors explain the differential performance of North and South American colonial and postcolonial economies and for their unattractiveness for immigration. The underlying nature of the property rights granted to land and minerals, their distribution among the population, as well as associated incentives for innovation, market development, political participation, and social mobility also likely played critical roles. The US South had similar factor and environmental characteristics to much of Latin America, but small freehold farms did emerge alongside plantations (Engerman and Sokoloff, 1997, 289). Economic, social, and political outcomes there were more similar to northern US than to Latin America. Moreover, in temperate Argentina, Uruguay, Chile, and southeast Brazil, the best lands were often preempted by large grant holders and small farmers had difficulties in obtaining title to their lands. Land conflicts due to incomplete property rights also occurred elsewhere in Latin America where small holdings were otherwise would have been economically viable (Sanchez, Lopez-Uribe, and Fazio, 2010). The relatively fewer immigrants to these regions more easily became tenants or were employed as agricultural laborers or range riders, gauchos, than small freeholders (Engerman and Sokoloff, 1997, 280; Garciá-Jimeno and Robinson, 2011). In this regard, the Latin American frontier seems to have had an enduring impact, as F.J. Turner argued for the US, but with very different consequences, because property rights were assigned to it in very different ways. 


\section{Conclusion.}

Property rights are the most fundamental institution in any society, an assessment recognized by early political economists and philosophers, as well as by later historians and legal scholars. Economists and economic historians have understood the direct economic importance of property rights, but the broader implications of the nature and distribution of the rights granted to land and minerals have not been central in recent research. Yet, these seem critical in explaining long-term differences in economic, political and social performance. Property rights determine who has decision-making authority over assets and who bears the costs and benefits of those decisions. They make markets possible; define timelines; and provide incentives investment, innovation, and trade. They mitigate the losses of open access and provide the basis for long-term economic growth. They assign ownership, wealth, political influence, and social standing. For these reasons, how property rights are defined and allocated to land and minerals determines who the players are and who has a lasting stake in the society and economy. The contrasting experiences of the North American and South American frontiers illustrate these arguments, and there likely are durable, path-dependent effects in the process of economic growth. The property rights distribution to land seem to have affected how citizens participated in capital and other markets and how they assessed their ability to advance economically, socially, and politically through markets as compared to state intervention. Whether and how the effects of broad ownership of land are maintained in more urban, developed economies requires research attention.

\section{References}

Abramitsky, R. and Braggion, F. (2006). Migration and Human Capital: Self-Selection of Indentured Servants to the Americas. Journal of Economic History 66 (4): 882-905.

Acemoglu, D., Johnson, S. and Robinson, J. (2001). The Colonial Origins of Comparative Development: An Empirical Investigation. American Economic Review 91 (5): 1369-1401.

Acemoglu, D., Johnson, S. and Robinson, J. (2002). Reversal of Fortune: Geography and Institutions in the Making of the Modern World Income. Distribution. The Quarterly Journal of Economics 117(4): 1231-1294.

Acemoglu, D., Johnson, S. and Robinson, J. (2005). The Rise of Europe: Atlantic trade, Institutional Change, and Economic Growth. 
American Economic Review 95 (3): 546-579.

Acemoglu, D. and Robinson, J. (2012). Why Nations Fail, New York: Crown.

Allen, D.W. (2011). The Institutional Revolution: Measurement and the Economic Emergence of the Modern World. Chicago: University of Chicago Press.

Alston, E., Alston L.J., Mueller, B., and Nonnenmacher, T. (Forthcoming, 2018). Institutional and Organizational Analysis: Concepts and Applications. New York: Cambridge University Press.

Alston, L.J., Harris, E., and Mueller, B. (2012). The Development of Property Rights on Frontiers: Endowments, Norms, and Politics. Journal of Economic History 72 (3): 741-70.

Arad, L.A. (2013). Persistent Inequality? Trade, Factor Endowments, and Inequality in Republican Latin America. Journal of Economic History 73 (1): 38-78.

Barro, R.J. (1991). Economic Growth in a Cross Section of Countries. The Quarterly Journal of Economics 106 (2): $407-443$.

Barzel, Y. (1997). Economic Analysis of Property Rights. New York: Cambridge University Press.

Bazzi, S., Fiszbein, M., and Gebresilasse, M. (2017). Frontier Culture: The Roots and Persistence of "Rugged Individualism" in the United States. NBER Working Paper No. 23997.

Besley, T.J. (1995). Property Rights and Investment Incentives: Theory and Evidence from Ghana. Journal of Political Economy 103 (5): $903-937$

Besley, T.J. and Ghatak, M. (2010). Property Rights and Economic Development. Rodrik, D. and Rosenzweig, M. (eds.). Handbook of Development Economics. Volume 5, New York: Elsevier: 4525-4595.

Cheung, S.N (1970). The Structure of a Contract and the Theory of a Non-Exclusive Resource. Journal of Law and Economics 13 (1): 49-70. 
Chowning, M. (1997). Reassessing the Prospects for Profit in Nineteenth-Century Mexican Agriculture from a Regional Perspective: Michoacán, 1810-60. In Haber, S. (ed.). How Latin America Fell Behind. Palo Alto: Stanford University Press: 179-215.

Coase, R. (1960). The Problem of Social Cost. Journal of Law and Economics 3: 1-44.

Clay, K. and Jones, R. (2008). Migrating to Riches? Evidence from the California Gold Rush. Journal of Economic History 68 (4): 997-1027.

Clay, K. and Wright, G. (2005). Order with Law? Property Rights and the California Gold Rush. Explorations in Economic History 42 (2): 155-183.

Costello, C., Gaines, S.D., and Lynham, J. (2008). Can Catch Shares Prevent Fisheries Collapse? Science 321:1678-1681.

Cox, M., Arnold, G. and Villamayor Tomás, S. (2010). A Review of Design Principles for Community-based Natural Resource Management. Ecology and Society 15 (4): 38. On Line: http://www.ecologyandsociety.org/vol15/iss4/art38/.

Dahlman, C. (1979). The Problem of Externality. Journal of Law and Economics 22: 141-162.

Davis, L.E. and North, D.C. (1971): Institutional Change and American Economic Growth. New York: Cambridge University Press.

de Tocqueville, A. (1835). Democracy in America. Translated by Goldhammer, A. (2004). New York: Penguin Putnam.

Dixit, A. (2009). Governance Institutions and Economic Activity. American Economic Review 99 (1): 3-24.

Donaldson, T. (1884). The Public Domain: Its History, with Statistics. Washington D.C.: Government Publishing Office.

Easterlin, R.A. (1960). Interregional Differences in Per Capita Income, Population, and total Income, 1840-1950. In Trends in the American Economy in the Nineteenth Century, The Conference on Research in Income and Wealth, NBER. Princeton: Princeton University Press: 73-140. 
Edwards, J. and Ogilvie, S. (2012). What Lessons for Economic Development Can We Draw from the Champagne Fairs? Explorations in Economic History 49 (2):131-148.

Ellickson, R.C. (1993). Property in Land. Yale Law Journal 102: 1315-1400.

Ely, J.W., Jr. (2008). The Guardian of Every Other Right: A Constitutional History of Property Rights. New York: Oxford University Press, $3^{\text {rd }}$ Edition.

Engerman, S.L. and Sokoloff, K.L. (1997). Factor Endowments, Institutions, and Differential Paths of Growth Among New World Economies. In Haber, S. (ed.). How Latin America Fell Behind. Palo Alto: Stanford University Press: 260-291.

Engerman, S.L. and Sokoloff, K.L. (2012). Economic Development in the Americas Since 1500. New York: Cambridge University Press.

Ferrie, J.P. (1993). 'We are Yankees Now': The Economic Mobility of Two Thousand Antebellum Immigrants to the United States. Journal of Economic History. 53 (2): 388-391.

Ford, A.C. (1910). Colonial Precedents of Our National Land System as it Existed in 1800. Madison: Bulletin of the University of Wisconsin, No. 352, History Series, 2 (2): 321-477.

Franklin, B. (1751/1845). Observations Concerning the Increase of Mankind, Peopling of Countries, etc.," in The Literature of Political Economy: A Classified Catalogue of Selected Publications... with Historical, Critical, and Biographical Notices. McCulloch, J. Boston: Longman, Brown, Green, and Longmans.

Frank, Z.L. (2001). Exports and Inequality: Evidence from the Brazilian Frontier, 1870-1937, Journal of Economic History 61 (1): $37-$ 58.

Galenson, D.W. and Pope, C.L. (1989). Economic and Geographic Mobility on the Farming Frontier: Evidence from Appanoose County, Iowa, 1850-1870. Journal of Economic History 49 (3): 635-655.

Galiani, S. and Schargrodsky, E. (2010). Property Rights for the Poor: Effects of Land Titling. Journal of Public Economics 94 (9-10): 
700-729.

García-Jimeno, C., and Robinson, J.A. (2011). “The Myth of the Frontier.” Understanding Long-Run Economic Growth: Geography, Institutions, and the Knowledge Economy. In Costa, D.L. and Lamoreaux, N.R. (eds.) Chicago: University of Chicago Press: 49-89.

Gates, P. (1968). History of Public Land Law Development. Washington D.C.: Public Land Law Review Commission.

Goldin, C. (1998). America's Graduation from High School: The Evolution and Spread of Secondary Schooling in the Twentieth Century. Journal of Economic History 58 (2): 345-374.

Goldin, C. (2001). The Human Capital Century and American Leadership: Virtues of the Past. Journal of Economic History. 61 (2): 263-292.

Goldin, C. and Katz, L.F. (2010). The Race between Education and Technology. Cambridge: Harvard University Press.

Gordon, H. S. (1954). The Economic Theory of a Common-Property Resource: The Fishery. The Journal of Political Economy 62 (2): 124-142.

Grafton, R.Q., Squires, D. and Fox, K.J. Fox. (2000). Private Property and Economic Efficiency: A Study of a Common-Pool Resource. Journal of Law and Economics 43 (2): 679-714.

Gregson, M.E. (1996). Wealth Accumulation and Distribution in the Midwest in the Late Nineteenth Century. Explorations in Economic History 33 (4): 524-538.

Greif, A., Milgrom, P. and Weingast, B.R. (1994). Coordination, Commitment, and Enforcement: The Case of the Merchant Guild. Journal of Political Economy 102 (4): 745-776.

Grubb, F. (1986). Redemptioner Immigration to Pennsylvania: Evidence on Contract Choice and Profitability. Journal of Economic History 46 (2): 407-418, 
Hennessy, A. (1978). The Frontier in Latin American History. Albuquerque: University of New Mexico Press.

Hibbard, B.H. (1924). A History of the Public Land Policies. New York: Macmillan.

Hill, J.M. (1912). The Mining Districts of the Western United States. Bulletin 507. U.S. Department of the Interior U.S. Geological Survey.

Hornbeck, R. (2010). Barbed Wire: Property Rights and Agricultural Development. Quarterly Journal of Economics, 125(2): 767-810.

Jacoby, H. G., Li, G. and Rozelle, S. (2002). Hazards of Expropriation: Tenure Insecurity and Investment in Rural China.” American Economic Review 92 (5): 1420-1447.

Johnson, R.N. and Libecap, G.D. (1982). Contracting Problems and Regulation: The Case of the Fishery. American Economic Review $72(5): 1005-1022$.

Kanazawa, M. T. (1996). Possession is Nine Points of the Law: The Political Economy of Early Public Land Disposal. Explorations in Economic History 33 (2): 227-249.

Katz, S.N. (1976): Thomas Jefferson and the Right to Property in Revolutionary America. Journal of Law and Economics. 19 (3): 467-488.

Kearl, J. R., Pope, C.L., and Wimmer, L.T. (1980). Household Wealth in a Settlement Economy: Utah, 1850-1870. Journal of Economic History 40, (3): 477-4 96.

Lacy, J.C. (1995). Going with the Current: The Genesis of the Mineral Laws of the United States. $41^{\text {st }}$ Rocky Mountain Mineral Law Institute. San Francisco: Mathew Bender/Lexus Nexus: 10-1-10-55.

Lebergott (1985). The Demand for Land: The United States, 1820-1860. Journal of Economic History. 45 (2): $181-212$.

Leff, N.H. (1997). Economic Development in Brazil, 1822-1913. In Haber, S. (ed.). How Latin America Fell Behind. Palo Alto: Stanford University Press: 34-64. 
Libecap, G.D. (1978): Economic Variables and the Development of the Law: The Case of Western Mineral Right. Journal of Economic History 38 (2): 338-362.

Libecap, G.D. (1981). Locking Up the Range: Federal Land Use Controls and Grazing. Cambridge: Ballinger Publishing, Co.

Libecap, G. D. (2007). The Assignment of Property Rights on the Western Frontier: Lessons for Contemporary Environmental and Resource Policy. Journal of Economic History 67 (2): 257-291.

Libecap, G.D. (2008). Open-Access Losses and Delay in the Assignment of Property Rights. Arizona Law Review 50 (2): $379-408$.

Libecap, G.D. (2016) Coasean Bargaining to Address Environmental Externalities. In Bertrand, E. and Menard, C.(Eds), The Elgar Companion to Ronald Coase. Northampton, MA: Edward Elgar: 97-109.

Libecap, G.D. and Wiggins, S.N. (1984): Contractual Responses to the Common Pool: Prorationing of Crude Oil Production. The American Economic Review 74 (1): 87-98.

Libecap, G. D., Lueck, D. and O'Grady, T. (2011). Large-Scale Institutional Changes: Land Demarcation in the British Empire. Journal of Law and Economics 54 (4): 295-327.

Lindert, P.H. and Williamson, J.G. (2013). American Incomes Before and After the Revolution, Journal of Economic History, 73 (3): $725-65$.

Lindert, P.H., and Williamson, J. G. (2014a). Unequal Growth: American Incomes since 1650. Princeton, New Jersey: Princeton University Press

Lindert, P.H. and Williamson, J.G. (2014b). American Colonial Incomes, 1650-1774, NBER Working paper 19861.

Linklater, A. (2013). Owning the Earth: The Transforming History of Land Ownership. New York: Bloomsbury. 
Mehlum, H., Moene, K. and Torvik, R. (2006). Institutions and the Resource Curse. Economic Journal 116: 1-20.

Merrill, T.W. and Smith, H.E. Property. New York: Oxford University Press.

North, D. C. (1981). Structure and Change in Economic History. New York: Norton.

North, D.C. (1990). Institutions, Institutional Change and Economic Performance. Cambridge University Press.

North, D. C. and Thomas, R. (1973). The Rise of the Western World: A New Economic History. New York: Cambridge University Press.

North, D. C., Wallis, J.J. and Weingast, B.R. (2009). Violence and Social Orders: A Conceptual Framework for Interpreting Recorded Human History. New York: Cambridge University Press.

Oberly, J.W. (1986). Westward Who? Estimates of Native White Interstate Migration After the War of 1812. Journal of Economic History 46 (2): 431-440.

Ostrom, E. (1990). Governing the Commons: The Evolution of Institutions for Collective Action. New York: Cambridge University Press.

Pigou, A. C. (1920). The Economics of Welfare. London: Macmillan.

Priest, C. (Forthcoming, 2019). Credit Nation. Princeton: Princeton University Press.

Robbins, R. M. (1942). Our Landed Heritage. The Public Domain 1776-1936. Princeton: Princeton University Press

Rodrik, D. (2008). Second-Best Institutions. American Economic Review 98 (2): 100-104.

Sanchez, F., Lopez-Uribe, M. and Fazio, A. (2010). Land Conflicts, Property Rights, and the Rise of the Export Economy in Colombia, 1850-1925. Journal of Economic History 70 (2): 378-99. 
Steckel, R. (1989). Household Migration and Rural Settlement in the United States, 1850-1860. Explorations in Economic History 26 (2): 190-218.

Story, J. (1858). Commentaries on the Constitution of the United States (Vol. 2). Boston, Massachusetts. Little Brown.

Go, S. and Lindert, P.N. (2010). The Uneven Rise of American Public Schools to 1850. Journal of Economic History 70 (1): 1-26.

Scott, A. (1955). The Fishery: The Objectives of Sole Ownership. Journal of Political Economy 63 (2): 116-124.

Steinbeck, J. (1939/1976). The Grapes of Wrath. New York: Penguin Books.

Stewart, J.I. (2009). Economic Opportunity or Hardship? The Causes of Geographic Mobility on the Agricultural Frontier, 1860-1880. Journal of Economic History 69 (1): 238-68.

Swierenga, R.P. (1966). Land Speculator "Profits" Reconsidered: Central Iowa as a Test Case. Journal of Economic History 26(1): 128.

Turner, F.J. (1893). The Significance of the Frontier in American History. Report of the American Historical Association: 199-227. http://www.archive.org/stream/1893annualreport00ameruoft/1893annualreport00ameruoft_djvu.txt.

Umbeck, John. (1977). “A Theory of Contract Choice and the California Gold Rush.” Journal of Law and Economics 20(2): 421-437.

U.S. Census Bureau (2012, September 6). Population Statistics. https://www.census.gov/dataviz/visualizations/001/

U.S. Public Lands Commission (1880). Report of the Public Lands Commission. 46th Congress, 2nd Session, House Executive Document 46. Washington D.C.: Government Printing Office.

von Ende, E. and Weiss, T. (1993). Consumption of Farm Output and Economic Growth in the Old Northwest, 1800-1860. Journal of Economic History 53(2): 308-318.

Wiggins, S. N. and Libecap, G.D. (1985). Oil Field Unitization: Contractual Failure in the Presence of Imperfect Information. American Economic Review 75 (3): 368-385. 
Wilen, J. E. (2005). Property Rights and the Texture of Rents in Fisheries. In Leal, D. (Ed.). Evolving Property Rights in Marine Fisheries. Lanham, MD: Rowman and Littlefield: 49-67.

Winch, D. (1965). Classical Political Economy and Colonies. Cambridge: Harvard University Press. 